M. Romero, M. Kovacova, J.Ma. Rincón, Effect of particle size on kinetic crystallization of an iron-rich glass, Journal of Materials Science, 43 (2008) 4135-4142; doi: 010.1007/s10853-007-2318-y

\title{
Effect of particle size on kinetics crystallization of an iron-rich glass
}

M. Romero ${ }^{1 *}$, M. Kovacova ${ }^{2}$, J. Ma. Rincón ${ }^{1}$

(1) Group of Glassy and Ceramic Materials. Department of Building Construction Systems. Institute of Construction Sciences Eduardo Torroja-CSIC. C/ Serrano Galvache, 4. 28033 Madrid, Spain.

(2) Department of Physical and Physicochemical Mineral Processing Methods. Institute of Geotechnics, Slovak Academy of Sciences. Watsonova, 45. 04353 Kosice, Slovak Republic.

* Author to whom all correspondence should be addressed

E-mail: mromero@,ietcc.csic.es

\begin{abstract}
The effect of glass particle size on the crystallization kinetics of an iron-rich glass from a nickel leaching waste has been investigated by means of differential thermal analysis (DTA). The results show that the crystallization of a pyroxene phase occurs by bulk nucleation from a constant number of nuclei. The crystallization mode and the dimensionality of crystals are strongly dependent of the glass particle size, being $100 \mu \mathrm{m}$ the critical size. Glass fractions with particle size $>100 \mu \mathrm{m}$ show three-dimensional crystals growth controlled by diffusion whereas a particle size $<100 \mu \mathrm{m}$ leads to an interface reaction mechanism with two-dimensional growth of crystals.
\end{abstract}

Keywords: iron-rich glass; Crystallization kinetics; Non-isothermal DTA analysis

\section{Introduction}

The term vitrification is commonly used to mean the process of converting a material into a glass-like amorphous solid, which is free from any crystalline structure. Glassceramic are ceramic materials formed through the controlled nucleation and crystallization of glass. Glass-ceramics were developed in the 1950s and find a wide variety of applications in different technological fields [1-5]. The earliest glass-ceramics were produced by a conventional glass route and subsequently crystallized, usually by heat treatment in two stages to give nucleation followed crystal growth. In recent years, the sintering method has proven as a technically available route for glass-ceramics manufacture. This process usually involves milling a glass frit into fine particles, which are then shaped by conventional forming techniques and subsequently heat treated to provide sintering and crystallization of glass particles. Sintering process is normally used when the parent glass shows a strong tendency for surface crystallization or complex shapes are required.

Because glass and glass-ceramics are known to have many commercial applications, the transformation of wastes into glass or glass-ceramics provides the opportunity for making useful, marketable products out of wastes. Vitrification as method of waste disposal was firstly applied in the 1970s to the immobilization of liquid high-level radioactive waste (HLW) [6-7]. Since then, there has been a considerable research in 
this field, which concludes that vitrification process leads to a stable glass that is far superior in terms of durability, strength, and leach resistance compared to other wastes stabilisation technologies [8-12].

Glass ceramic method has been also used for the disposal of a wide diversity of nonnuclear inorganic wastes originated in both industrial and mineral processes [13]. In this case, wastes are transformed into valuable products for subsequent use as ceramic floor tiles, abrasives or concrete additives. Among industrial wastes, special attention is paid on those with high iron oxide content, which leads to glass-ceramic materials characterized by high mechanical strength and good chemical stability. In last years, iron-rich glass-ceramics have been obtained from zinc hydrometallurgy wastes [14-16], electric arc furnace dusts (EAFD) from the steel production [17-19], copper flotation wastes [20] and coal ashes [21].

Usually, inorganic wastes must be combined with glass-forming raw materials to develop by heating a melt that then solidifies during cooling and gives rise to a glass. In occasions, batch compositions containing wastes lead to melts with high tendency to crystallize during cooling and the vitreous state can be only achieved through fast cooling by pouring the melt on water to obtain a frit. In these cases, glass-ceramics can be only prepared by sintering route and the particle size of glass grains will play an important role in the crystallization process.

The aim of the present work is to determine the effect of glass particle size on the crystallization kinetics of an iron-rich glass produced by melting of a nickel leaching residue (NLR) from hydrometallurgical nickel production.

\section{Materials and Methods}

Raw materials used in the present investigation were a nickel leaching residue (NLR), glass cullet and dolomite. NLR is a waste coming from nickel production from Albanian laterite ore in a hydrometallurgical plant in Sered' (Slovakia). The annually production was around $3 \times 10^{5}$ tons and since the production finished in 1993, near to $5.5 \times 10^{6}$ tons waste remain at the dump. Even though the NLR contain more than 60 $\mathrm{wt} \%$ of iron in oxide form, it is not suitable as feed for steelmaking industry because of its high content of chromium. Table 1 shows the chemical composition of raw materials as determined by atomic absorption spectroscopy (AAS). Iron oxide is the main component in NLR, which also shows a low content of both glass-forming $\left(\mathrm{SiO}_{2}\right)$ and stabilising oxides (alkaline earth oxides). For this reason, glass cullet and dolomite have been used in the formulation of NLR glass, which was prepared by mixing $30 \%$ NLR, $60 \%$ glass cullet and $10 \%$ dolomite. Homogenized batches were placed in aluminasilica crucibles and heated at $15^{\circ} \mathrm{C} / \mathrm{min}$ in a high-temperature electric furnace up to $1450^{\circ} \mathrm{C}$. After a holding time of $30 \mathrm{~min}$, the melt was quenched by pouring into water.

To investigate the effect of particle size on crystallization kinetics of NLR glass, the frit was separated by sieving in six fractions with different particle size ranges as is shown in Table 2. 
M. Romero, M. Kovacova, J.Ma. Rincón, Effect of particle size on kinetic crystallization of an iron-rich glass, Journal of Materials Science, 43 (2008) 4135-4142; doi: 010.1007/s10853-007-2318-y

Table 1. Chemical analysis (wt $\%$ ) of raw materials determined by AAS

\begin{tabular}{|c|c|c|c|}
\hline Oxide & NLR & Glass cullet & Dolomite \\
\hline $\mathrm{SiO}_{2}$ & 15.03 & 72.4 & 0.59 \\
\hline $\mathbf{A l}_{2} \mathbf{O}_{3}$ & 4.80 & 1.7 & 0.34 \\
\hline $\mathrm{CaO}$ & 3.54 & 9.6 & 29.61 \\
\hline MgO & 2.21 & 1.7 & 22.47 \\
\hline $\mathrm{Fe}_{2} \mathrm{O}_{3}$ & 38.57 & 0.05 & 0.29 \\
\hline $\mathrm{FeO}$ & 22.64 & --- & --- \\
\hline $\mathrm{Na}_{2} \mathrm{O}$ & --- & 13.8 & 0.04 \\
\hline $\mathbf{K}_{2} \mathbf{O}$ & --- & 0.6 & 0.11 \\
\hline $\mathrm{Cr}_{2} \mathrm{O}_{3}$ & 1.06 & --- & --- \\
\hline NiO & 0.17 & --- & --- \\
\hline LOI & 11.98 & --- & 46.35 \\
\hline
\end{tabular}

Table 2. Particle size ranges separate by sieving from NLR frit

\begin{tabular}{cc}
\hline Fraction & Particle size range $(\boldsymbol{\mu m})$ \\
\hline f1 & $400-500$ \\
f2 & $250-400$ \\
f3 & $100-250$ \\
f4 & $80-100$ \\
f5 & $63-80$ \\
f6 & $<63$ \\
\hline
\end{tabular}

The vitreous or crystalline state of NRL glass before and after thermal treatment was established by X-ray diffractometry. Samples were crushed to fine powder in an agate mortar, passed through a 300 mesh sieve and then were scanned with $\mathrm{CuK} \alpha$ radiation from $3^{\circ} \leq 2 \theta \leq 60^{\circ}$ at a scanning speed of $0.5^{\circ} / \mathrm{min}$, using a Philips X'PERT MPD diffractometer operating at $30 \mathrm{~mA}$ and $50 \mathrm{kV}$.

Differential thermal analysis (DTA/TG) was performed on NLR glass fractions in a SETARAM Labsys Thermal Analyser. The samples were heated from room temperature to $1250^{\circ} \mathrm{C}$ at heating rates of $5,10,15,25,40$ and $50^{\circ} \mathrm{C} / \mathrm{min}$. The DTA scans were conducted in flowing air using platinum crucibles with calcined $\mathrm{Al}_{2} \mathrm{O}_{3}$ as reference material. All the DTA curves were normalised with respect to the sample weight.

The analysis of crystallization kinetics has been accomplished from DTA curves in basis of the Johnson-Mehl-Avrami (JMA) theory, which describes the evolution of the 
crystallization fraction, $x$, with the time, $t$, during a phase transformation under an isothermal condition.

$$
x=1-\exp \left[-(k t)^{n}\right]
$$

where $x$ is the volume fraction crystallized after time $t, n$ the Avrami exponent and $k$ the reaction rate constant, whose temperature dependence is generally expressed by the Arrhenian type equation:

$$
k=k_{0} \exp (-E / R T)
$$

where $k_{0}$ is the frequency factor, $\mathrm{E}$ is the apparent activation energy, $\mathrm{R}$ is the ideal gas constant and $\mathrm{T}$ is the isothermal temperature in Kelvin.

The crystallization rate can be expressed by:

$$
\frac{d x}{d t}=k f(x)=k_{0} \exp \left(-\frac{E}{R T}\right) f(x)
$$

and taking logarithms,

$$
\ln \left(\frac{d x}{d t}\right)=\ln \left[k_{0} f(x)\right]-\frac{E}{R T}
$$

These equations have been derived for isothermal crystallization process but they can be applied with certain restrictions to non-isothermal experiments with satisfactory results [22].

During a phase transformation under an isothermal condition the crystallization fraction, $x$, at a temperature $T$ differs at different heating rates and hence, the curves of $\mathrm{d} x / \mathrm{d} t$ versus temperature are also different. In this case, the crystallization kinetic can be studied by the mathematical method proposed by Ligero et al. [23], which has been effectively applied for interpreting DTA results from different materials [24-26]. If we select the same value of $x$ in every experiment at different heating rates, there should be a linear relationship between the corresponding $\mathrm{d} x / \mathrm{d} t$ and $1 / \mathrm{T}$, whose slope gives the activation energy, $E$. Then, it is possible to calculate, through Eq. (4), the value of $\ln \left[k_{0}\right.$ $f(x)]$ for each crystallized fraction at each heating rate. From the plot of $\ln \left[k_{0} f(x)\right]$ versus $x$, we can select many pairs of $x_{1}$ and $x_{2}$ that satisfied the condition

$$
\ln \left[k_{0} f\left(x_{1}\right)\right]=\ln \left[k_{0} f\left(x_{2}\right)\right]
$$

and therefore,

$$
\ln \left(1-x_{1}\right)+\frac{n-1}{n} \ln \left[-\ln \left(1-x_{1}\right)\right]=\ln \left(1-x_{2}\right)+\frac{n-1}{n} \ln \left[-\ln \left(1-x_{2}\right)\right]
$$

and the Avrami parameter, $n$, can be calculated by, 
$n=\ln \left[\ln \left(1-x_{2}\right) / \ln \left(1-x_{1}\right)\right] / \ln \left[\frac{\left(1-x_{2}\right) \ln \left(1-x_{2}\right)}{\left(1-x_{1}\right) \ln \left(1-x_{1}\right)}\right]$

Once the Avrami parameter is determined, the frequency factor, $\mathrm{k}_{0}$, can also be calculated by equation:

$$
\ln \left[k_{0} f(x)\right]=\ln k_{0}+\ln n+\ln (1-x)+\frac{n-1}{n} \ln [-\ln (1-x)]
$$

The Avrami parameter, $n$, indicates the crystallization mode. Another useful parameter is the numerical factor, $m$, which depends on the dimensionality of crystal growth and is derived from the Matusita and Sakka equation for non-isothermal DTA experiments [27-29]:

$$
\ln \left(\frac{\phi^{n}}{T_{p}^{2}}\right)=-\frac{m E}{R T_{p}}+\text { const }
$$

where $\phi$ is the heating rate and $T_{p}$ is the temperature at the maximum of crystallization peak.

\section{Results and Discussion}

The glassy nature of the as-quenched frit is established by XRD in Figure 1, which depicts the typical amorphous halo characteristic of glassy materials. Table 3 shows the chemical analysis by XRF of NLR glass, being $\mathrm{SiO}_{2}, \mathrm{Fe}_{2} \mathrm{O}_{3}$ and $\mathrm{CaO}$ the major components. Compare to other silicate glasses, NLR glass is distinguished by a high iron oxide content, which will confer a high crystallization tendency to the glass. In fact, this composition can be only achieved in a glassy state by means of fast cooling by pouring the melt on water.

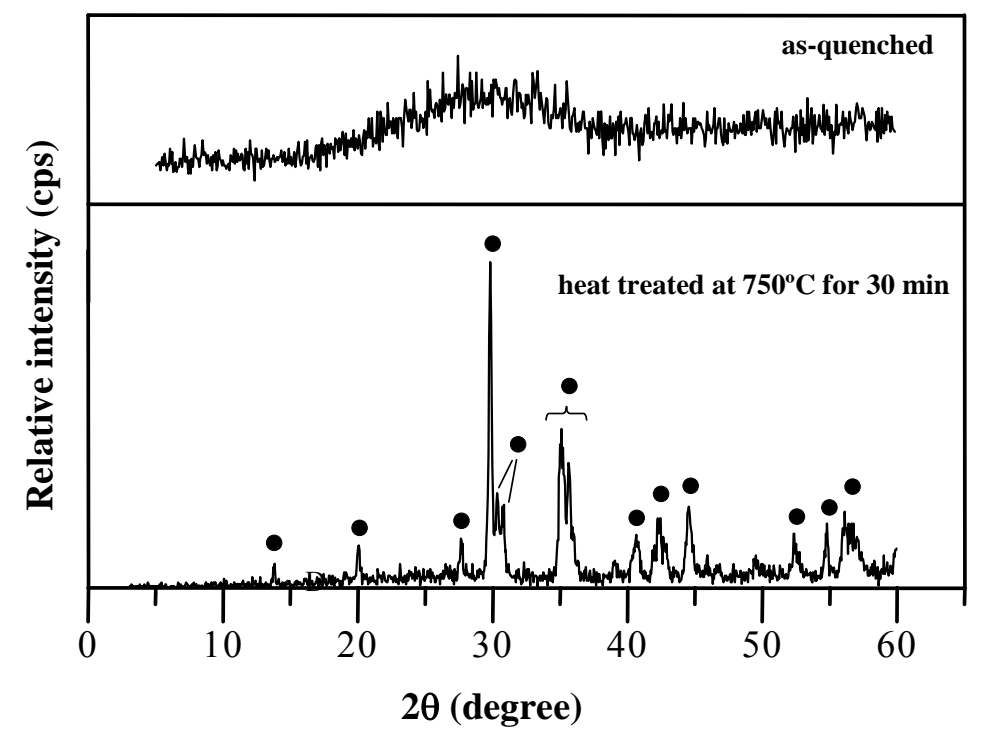

Figure 1. XRD patterns of NLR glass frit as-quenched and after heat treatment at $750^{\circ} \mathrm{C}$ during $30 \min (\mathbf{O}=$ pyroxene phase from the diopside-hedenbergite series). 
M. Romero, M. Kovacova, J.Ma. Rincón, Effect of particle size on kinetic crystallization of an iron-rich glass, Journal of Materials Science, 43 (2008) 4135-4142; doi: 010.1007/s10853-007-2318-y

Table 3. Chemical analysis (wt\%) of NLR glass as determined by XRF

\begin{tabular}{ccccccccc}
\hline $\mathrm{SiO}_{2}$ & $\mathrm{Al}_{2} \mathrm{O}_{3}$ & $\mathrm{Fe}_{2} \mathrm{O}_{3}$ & $\mathrm{CaO}$ & $\mathrm{MgO}$ & $\mathrm{Na}_{2} \mathrm{O}$ & $\mathrm{K}_{2} \mathrm{O}$ & $\mathrm{TiO}_{2}$ & $\mathrm{Cr}_{2} \mathrm{O}_{3}$ \\
\hline 48,07 & 3,59 & 22,34 & 11,79 & 4,62 & 7,77 & 0,66 & 0,09 & 1,06 \\
\hline
\end{tabular}

Figure 2 shows representative DTA curve recorded on $80-100 \mu \mathrm{m}$ fraction during heating from room temperature to $1250^{\circ} \mathrm{C}$ at a heating rate of $25^{\circ} \mathrm{C} \mathrm{min}{ }^{-1}$. The glass shows the glass transition, $\mathrm{Tg}$, at $610^{\circ} \mathrm{C}$ followed by an only exothermic crystallization peak, $\mathrm{T}_{\mathrm{p}}$, in the $755^{\circ}-783^{\circ} \mathrm{C}$ range. Finally, and endothermic reaction at $1035^{\circ} \mathrm{C}$ indicates formation of a liquid phase. The exothermic peak is due to the crystallization of a pyroxene phase from the diopside-hedenbergite group, which forms a completed solidsolution series between $\mathrm{CaMgSi}_{2} \mathrm{O}_{6}$ (diopside) and $\mathrm{CaFeSi}_{2} \mathrm{O}_{6}$ (hedenbergite) [30], as has been identified by XRD analysis on NLR glass sintered at $750^{\circ} \mathrm{C}$ during $30 \mathrm{~min}$ (Figure 1). Pyroxene-type phases are typical phases precipitated in glass-ceramics from iron-rich wastes, in which crystallization occurs through liquid-liquid immiscibility, where one of the liquid phases is richer in iron and promotes a spontaneous formation of the magnetite spinels nano-crystals, which act as nuclei for the formation of the main pyroxene phase $[31,32]$.

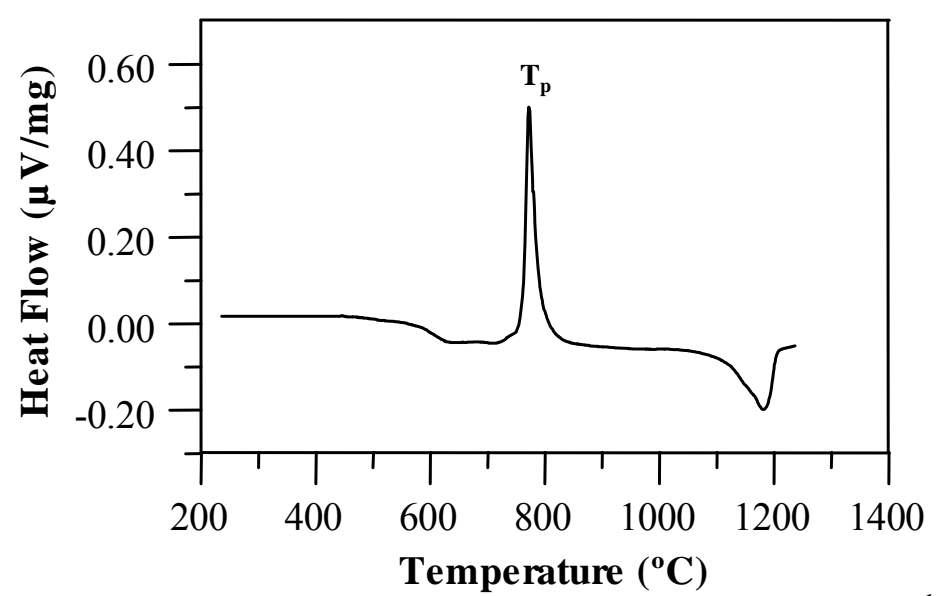

Figure 2. DTA curve from $\mathrm{f} 4$ fraction $(80-100 \mu \mathrm{m})$ heated at $25^{\circ} \mathrm{C} \mathrm{min}^{-1}$.

Figure 3 depicts the DTA curves recorded on different particle size fractions of NLR glass at a heating rate of $25^{\circ} \mathrm{C}$. The temperature of the maximum of the exothermic peak, Tp, shifts to a higher temperature as the particle size decrease from 500 to $<63 \mu \mathrm{m}$. In addition, the height and width of crystallization peak is also changing. Thus, Fig. 3 indicates that the crystallization kinetics of NLR glass will be highly subject to the glass particle size.

As is usual in glasses, if we consider a specific particle size fraction, the temperature of the maximum of the exothermic peak, $T_{c}$, shifts to higher temperatures as the heating rate increases. As instance, Figure 4 depicts the DTA curves recorded on the $80-100 \mu \mathrm{m}$ fraction at different heating rates. From each of those curves, the crystallization fraction, $x$, can be determined by the ratio: 
$x=\frac{A_{T}}{A}$,

where $A_{T}$ is the area of the exotherm peak in the DTA curve at temperature $T$ and $A$ is the total area under the peak.

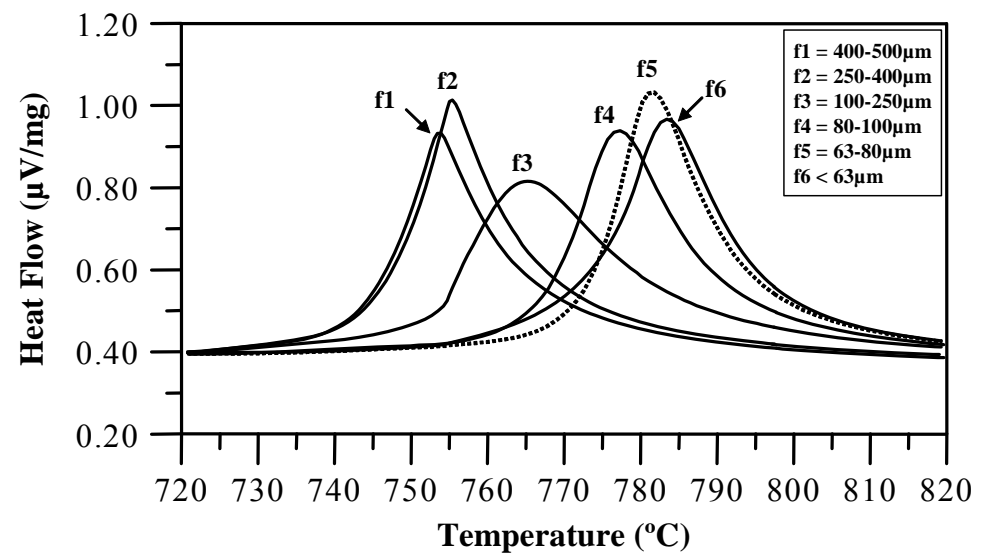

Figure 3. DTA curves for different particle size fractions of NLR glass at a heating rate of $25^{\circ} \mathrm{C}$.

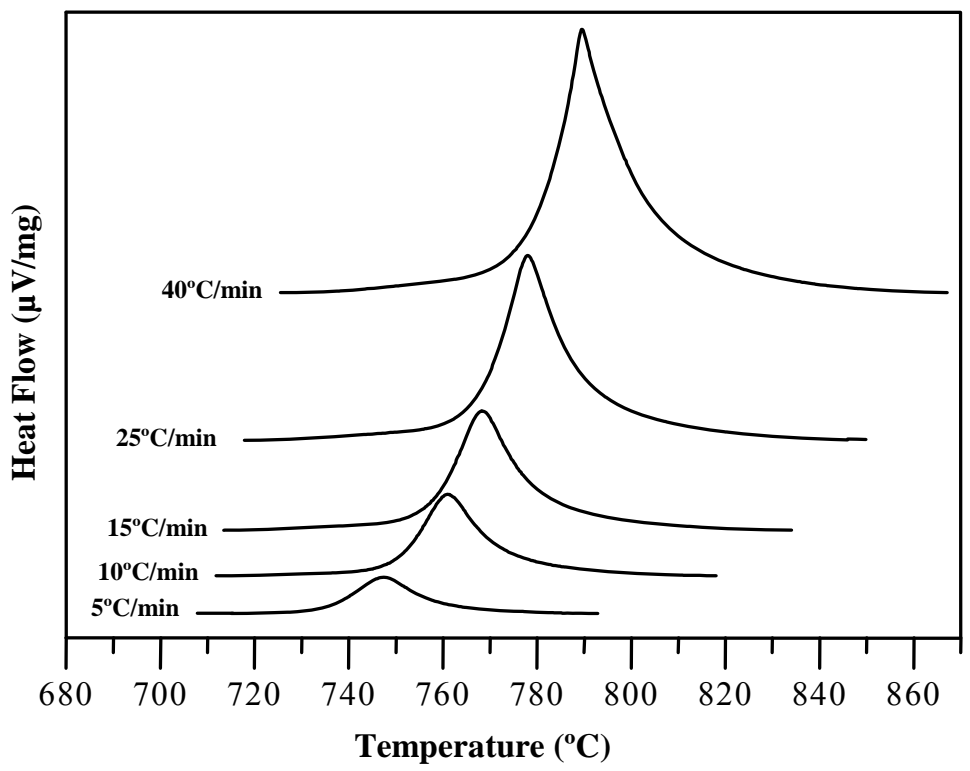

Figure 4. DTA curves fromf4 fraction $(80-100 \mu \mathrm{m})$ at different heating rates.

Figure 5 represents the variation of $x$ with temperature for the $80-100 \mu \mathrm{m}$ fraction under different heating rates. As presumed from the different size of curves in Fig. 4, the crystallization fraction at a fixed temperature varies with heating rates and consequently, the representations of $\mathrm{dx} / \mathrm{dt}$ versus time are also different as is shown in Figure 6, which depicts the growth rate of pyroxene phase with time for different heating rates. As expected, the rate of crystallization increases with the heating rate. 


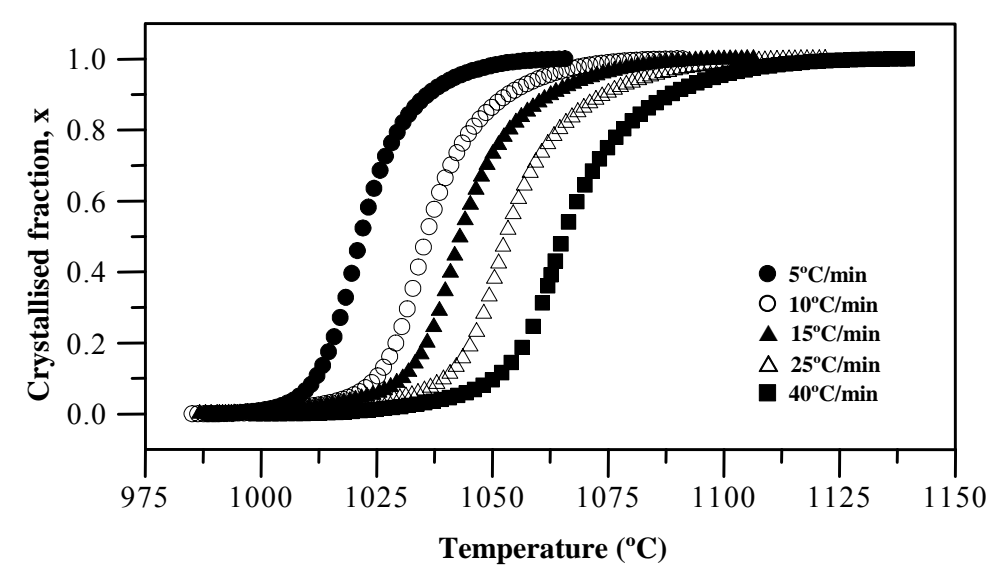

Figure 5. Variation of crystallized fraction with temperature for $\mathrm{f} 4$ fraction $(80-100 \mu \mathrm{m})$ under different heating rates.

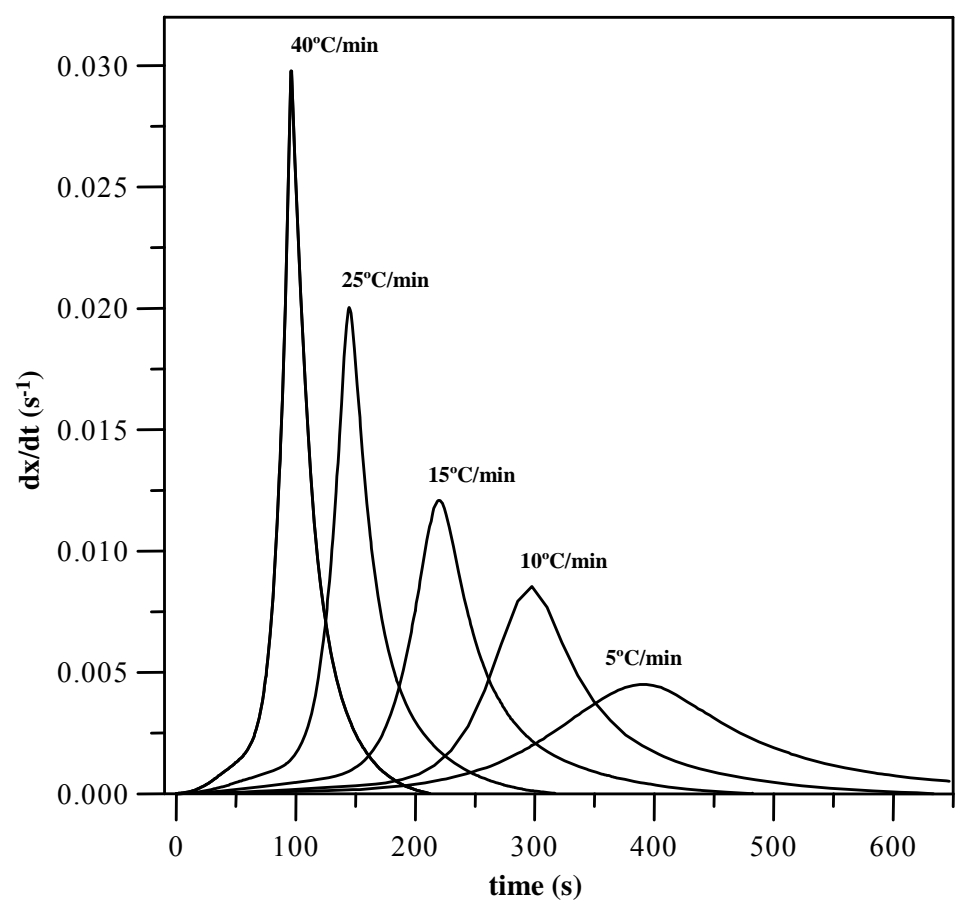

Figure 6. Growth rate of pyroxene phase with time for $\mathrm{f} 4$ fraction $(80-100 \mu \mathrm{m})$ at different heating rates.

Figure 7 depicts the plot of $\ln (\mathrm{dx} / \mathrm{dt})$ versus $1 / \mathrm{T}$ at the same value of crystallized fraction from the experiment carried out on $\mathrm{f} 4$ fraction $(80-100 \mu \mathrm{m})$ at different heating rates. Analogous curves are obtained for the different particle size fractions. For each fraction, it is possible to select a crystallized fraction range for which $\ln (\mathrm{dx} / \mathrm{dt})$ fits a straight line with the absolute temperature inverse. The activation energy, E, can be then determined from the slope of those lines. The values of $\mathrm{E}$ calculated the different crystallized fractions and the average values for the different particle size fractions are listed in Table 4. For calculations, only values of crystallized fraction that lead to highly reliable fitting (coefficient of determination, $r>0.99$ ) have been taken into account. The average activation energy of pyroxene phase devitrification for the different particle size fractions is shown in Figure 8. It can be seen that the fractions can be sorted out in two groups with $100 \mu \mathrm{m}$ as the critical particle size. This result indicates that the 
crystallization in NLR glass occurs by different mechanisms depending on the glass particle size. This fact will be explained afterwards.

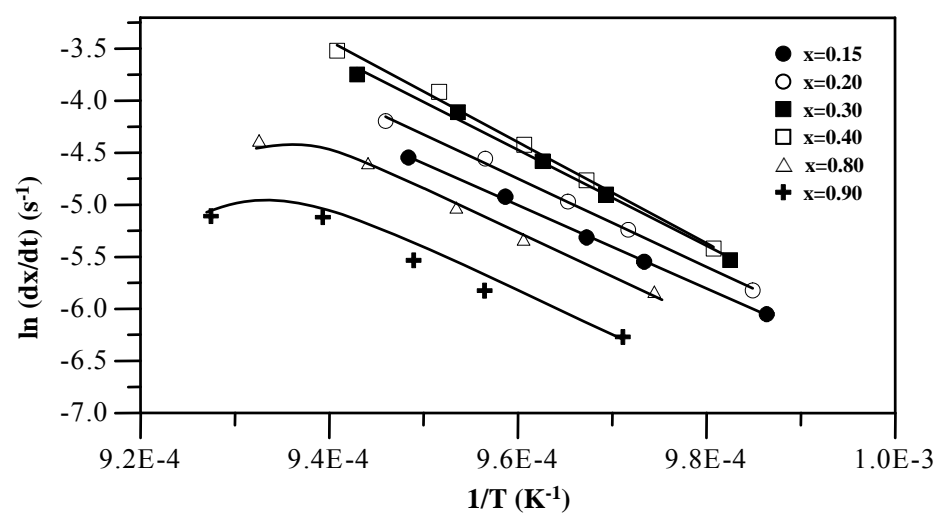

Figure 7. Plot of $\ln (\mathrm{dx} / \mathrm{dt})$ versus $1 / \mathrm{T}$ at the same value of crystallized fraction from the experiment carried out on $\mathrm{f} 4$ fraction $(80-100 \mu \mathrm{m})$ at different heating rates.

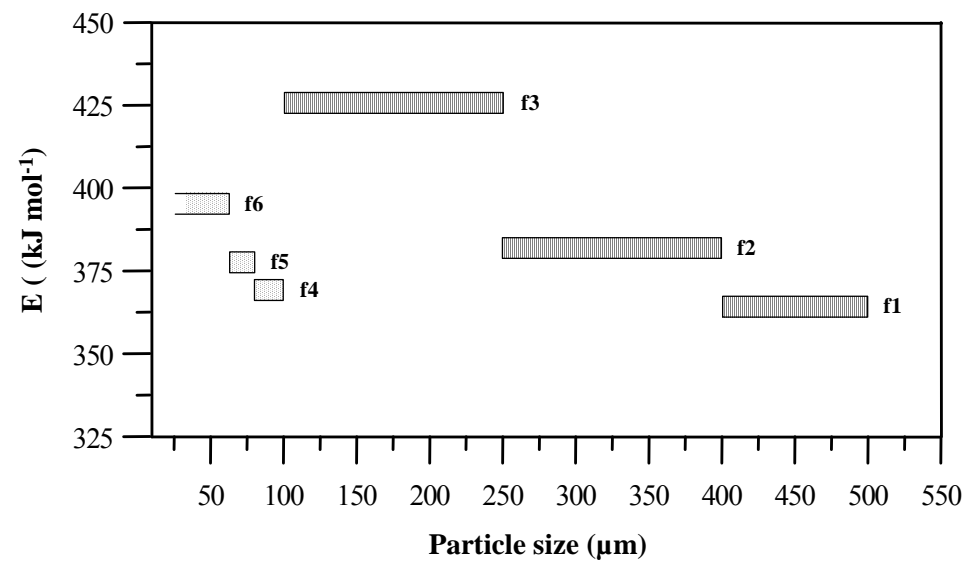

Figure 8. Average activation energy of pyroxene phase devitrification for the different particle size fractions.

The value of $\ln \left[\mathrm{k}_{0} \mathrm{f}(\mathrm{x})\right]$ for the different particle size fractions can be calculated once their activation energy is known and the Avrami parameter, $\mathrm{n}$, is determined by selecting several pairs of $x_{1}$ and $x_{2}$ that satisfy the condition $\ln \left[k_{0} f\left(x_{1}\right)\right]=\ln \left[k_{0} f\left(x_{2}\right)\right]$. Figure 9 shows the plot of $\ln \left[\mathrm{k}_{0} \mathrm{f}(\mathrm{x})\right]$ versus crystallization fraction for $80-100 \mu \mathrm{m}$ fraction heated at $25^{\circ} \mathrm{C} \mathrm{min}^{-1}$. Similar curves are obtained for the different heating rates and particle size fractions. Table 5 collects the calculated values at different heating rates and the average values of Avrami parameter, $\mathrm{n}$, and the frequency factor, $\mathrm{k}_{0}$. It can be seen that there is a strong step in the magnitude of $\mathrm{k}_{0}$ from $80-100 \mu \mathrm{m}$ fraction $\left(\mathrm{k}_{0}=3.72 \times 10^{15} \mathrm{~s}^{-1}\right)$ to $100-250 \mu \mathrm{m}$ fraction $\left(\mathrm{k}_{0}=1.4 \times 10^{19} \mathrm{~s}^{-1}\right)$. As the frequency factor is related to the vibration frequency of atoms in the interface crystal-liquid [33], the observed change is indicating a strong viscosity variation just around the critical particle size $(100 \mu \mathrm{m})$.

Figure 10 shows the fitting of Matusita equation (9) for the different particle size fractions. Once the values of $\mathrm{n}$ and $\mathrm{E}$ are known, the slope of the lines yields the $m$ factor. 
Table 4. Values of E calculated for the different particle size fractions

\begin{tabular}{|c|c|c|c|c|}
\hline Particle size & Crystallized fraction & $\mathbf{r}$ & $E_{x}\left(k^{\prime} \mathrm{mol}^{-1}\right)$ & $\mathrm{E}\left(\mathrm{kJ} \mathrm{mol}{ }^{-1}\right)$ \\
\hline \multirow{8}{*}{$<63 \mu \mathrm{m}$} & $x=0.12$ & 0.989 & - & \multirow{8}{*}{386} \\
\hline & $x=0.13$ & 0.992 & 366 & \\
\hline & $x=0.15$ & 0.995 & 368 & \\
\hline & $x=0.20$ & 0.997 & 377 & \\
\hline & $x=0.30$ & 0.997 & 393 & \\
\hline & $x=0.40$ & 0.993 & 407 & \\
\hline & $x=0.41$ & 0.991 & 405 & \\
\hline & $\mathrm{x}=0.42$ & 0.988 & - & \\
\hline \multirow{7}{*}{$63-80 \mu \mathrm{m}$} & $x=0.10$ & 0.986 & - & \multirow{7}{*}{365} \\
\hline & $\mathrm{x}=0.11$ & 0.996 & 363 & \\
\hline & $x=0.12$ & 0.993 & 357 & \\
\hline & $x=0.15$ & 0.992 & 366 & \\
\hline & $x=0.17$ & 0.991 & 370 & \\
\hline & $x=0.18$ & 0.992 & 368 & \\
\hline & $x=0.19$ & 0.987 & - & \\
\hline \multirow{8}{*}{$80-100 \mu \mathrm{m}$} & $\mathrm{x}=0.10$ & 0.991 & 325 & \multirow{8}{*}{351} \\
\hline & $\mathrm{x}=0.12$ & 0.996 & 333 & \\
\hline & $x=0.15$ & 0.999 & 343 & \\
\hline & $x=0.20$ & 0.997 & 352 & \\
\hline & $x=0.30$ & 0.995 & 372 & \\
\hline & $x=0.40$ & 0.996 & 384 & \\
\hline & $x=0.45$ & 0.991 & 374 & \\
\hline & $x=0.46$ & 0.898 & - & \\
\hline \multirow{7}{*}{$100-250 \mu \mathrm{m}$} & $x=0.10$ & 0.999 & 422 & \multirow{7}{*}{423} \\
\hline & $x=0.20$ & 0.998 & 417 & \\
\hline & $x=0.30$ & 0.998 & 420 & \\
\hline & $x=0.40$ & 0.997 & 429 & \\
\hline & $x=0.50$ & 0.996 & 428 & \\
\hline & $x=0.60$ & 0.994 & 422 & \\
\hline & $x=0.63$ & 0.898 & - & \\
\hline \multirow{7}{*}{$250-400 \mu \mathrm{m}$} & $\mathrm{x}=0.10$ & 0.996 & 356 & \multirow{7}{*}{370} \\
\hline & $x=0.15$ & 0.996 & 352 & \\
\hline & $\mathrm{x}=0.20$ & 0.994 & 358 & \\
\hline & $x=0.25$ & 0.994 & 372 & \\
\hline & $x=0.30$ & 0.994 & 389 & \\
\hline & $x=0.32$ & 0.992 & 395 & \\
\hline & $x=0.33$ & 0.989 & - & \\
\hline \multirow{7}{*}{$400-500 \mu \mathrm{m}$} & $x=0.10$ & 0.995 & 353 & \multirow{7}{*}{349} \\
\hline & $x=0.11$ & 0.996 & 342 & \\
\hline & $x=0.13$ & 0.992 & 344 & \\
\hline & $x=0.15$ & 0.991 & 349 & \\
\hline & $x=0.17$ & 0.991 & 351 & \\
\hline & $x=0.18$ & 0.991 & 354 & \\
\hline & $x=0.19$ & 0.987 & - & \\
\hline
\end{tabular}


M. Romero, M. Kovacova, J.Ma. Rincón, Effect of particle size on kinetic crystallization of an iron-rich glass, Journal of Materials Science, 43 (2008) 4135-4142; doi: 010.1007/s10853-007-2318-y

Table 5. Values of $\mathrm{n}$ calculated for the different particle size fractions

\begin{tabular}{|c|c|c|c|c|c|}
\hline $\begin{array}{c}\text { Particle size } \\
(\mu \mathrm{m})\end{array}$ & $\begin{array}{l}\text { Heating rate } \\
\qquad\left({ }^{\circ} \mathrm{C} \mathrm{min}^{-1}\right)\end{array}$ & $\mathbf{n}_{\phi}$ & $\mathbf{n}$ & $\mathbf{k}_{\mathbf{0}, \phi}\left(\mathbf{s}^{-\mathbf{1}}\right)$ & $k_{0}\left(s^{-1}\right)$ \\
\hline$<63$ & $\begin{array}{c}5 \\
10 \\
15 \\
25 \\
40\end{array}$ & $\begin{array}{l}1.75 \\
1.63 \\
1.57 \\
1.63 \\
1.67\end{array}$ & $1.65 \pm 0.06$ & $\begin{array}{l}1.34 \times 10^{17} \\
1.39 \times 10^{17} \\
1.17 \times 10^{17} \\
1.69 \times 10^{17} \\
8,64 \times 10^{16}\end{array}$ & $1.29 \times 10^{17}$ \\
\hline $63-80$ & $\begin{array}{c}5 \\
10 \\
15 \\
25 \\
40\end{array}$ & $\begin{array}{l}1.65 \\
1.56 \\
1.53 \\
1.56 \\
1.53\end{array}$ & $1.56 \pm 0.05$ & $\begin{array}{l}1.09 \times 10^{16} \\
9.40 \times 10^{15} \\
8.99 \times 10^{15} \\
1.04 \times 10^{16} \\
9.25 \times 10^{15}\end{array}$ & $9.79 \times 10^{15}$ \\
\hline $80-100$ & $\begin{array}{c}5 \\
10 \\
15 \\
25 \\
40\end{array}$ & $\begin{array}{l}1.68 \\
1.65 \\
1.53 \\
1.50 \\
1.49\end{array}$ & $1.57 \pm 0.08$ & $\begin{array}{l}4.31 \times 10^{15} \\
3.59 \times 10^{15} \\
3.49 \times 10^{15} \\
3.73 \times 10^{15} \\
3.49 \times 10^{15}\end{array}$ & $3.72 \times 10^{15}$ \\
\hline $100-250$ & $\begin{array}{c}5 \\
10 \\
15 \\
25 \\
40\end{array}$ & $\begin{array}{l}1.47 \\
1.44 \\
1.42 \\
1.34 \\
1.36\end{array}$ & $1.40 \pm 0.05$ & $\begin{array}{l}1.55 \times 10^{19} \\
1.52 \times 10^{19} \\
1.43 \times 10^{19} \\
1.26 \times 10^{19} \\
1.23 \times 10^{19}\end{array}$ & $1.40 \times 10^{19}$ \\
\hline $250-400$ & $\begin{array}{c}5 \\
10 \\
15 \\
25 \\
40\end{array}$ & $\begin{array}{l}1.46 \\
1.49 \\
1.50 \\
1.43 \\
1.38\end{array}$ & $1.45 \pm 0.05$ & $\begin{array}{l}4.84 \times 10^{16} \\
5.78 \times 10^{16} \\
6.65 \times 10^{16} \\
4.92 \times 10^{16} \\
3.87 \times 10^{16}\end{array}$ & $5.21 \times 10^{16}$ \\
\hline $400-500$ & $\begin{array}{c}5 \\
10 \\
15 \\
25 \\
40\end{array}$ & $\begin{array}{l}1.60 \\
1.40 \\
1.43 \\
1.45 \\
1.47\end{array}$ & $1.49 \pm 0.08$ & $\begin{array}{l}5.32 \times 10^{15} \\
7.80 \times 10^{15} \\
5.25 \times 10^{15} \\
4.98 \times 10^{15} \\
3.90 \times 10^{15}\end{array}$ & $5.45 \times 10^{15}$ \\
\hline
\end{tabular}




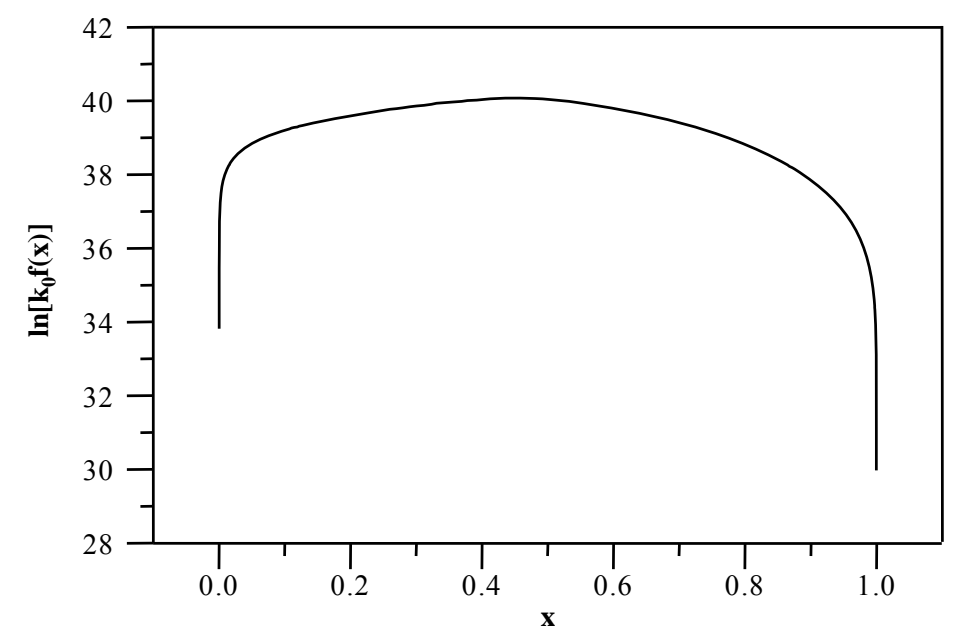

Figure 9. Plot of $\ln \left[\mathrm{k}_{0} \mathrm{f}(\mathrm{x})\right]$ versus crystallization fraction for $80-100 \mu \mathrm{m}$ fraction heated at $25^{\circ} \mathrm{C} \mathrm{min}^{-1}$.

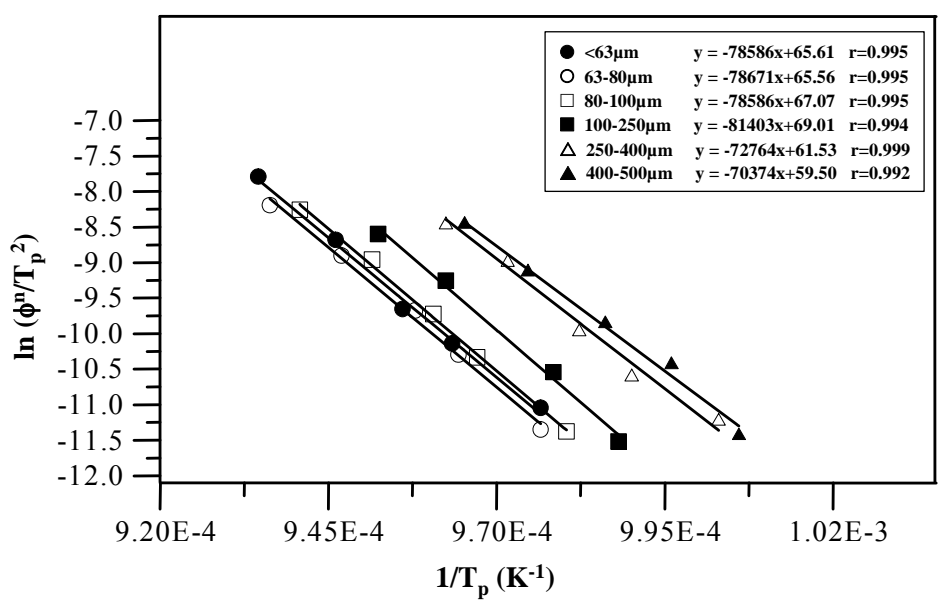

Figure 10. Fitting of Matusita equation for the different particle size fractions.

Figure 11 depicts the location of $\mathrm{fl}-\mathrm{f} 6$ fractions regarding their values of $\mathrm{n}$ and $\mathrm{m}$ comparing to different crystallization mechanisms according to Matusita et al. [34]. All fractions are located on the region of bulk nucleation mechanism with constant number of nuclei. However, it can be seen that in agreement with Fig. 8, the fractions are arranged in two groups. The parameters $\mathrm{n}$ and $\mathrm{m}$ are both close to 1.5 in fractions with particle size $>100 \mu \mathrm{m}$, which is an indication, according to Matusita, of a diffusion controlled mechanism with three-dimensional growth of pyroxene crystals with polyhedron-like morphology. As to finer fractions with particle size $<100 \mu \mathrm{m}, \mathrm{n}$ and $\mathrm{m}$ parameters are shifted to values close to 2, which indicates an interface reaction mechanism with two-dimensional growth of pyroxene crystals with plates-like morphology. The values of $\mathrm{n}$ for $\mathrm{fl}-\mathrm{f} 6$ fractions are in the 1.40-1.65 interval, which is in agreement with values of $\mathrm{n}$ in the 1.2-1.8 interval previously reported on iron-rich glasses $[16,21,32]$. As for $m$ parameter, there is a lack in the literature on the determination of such parameter and hence, it was not possible to evaluate against similar glasses. 


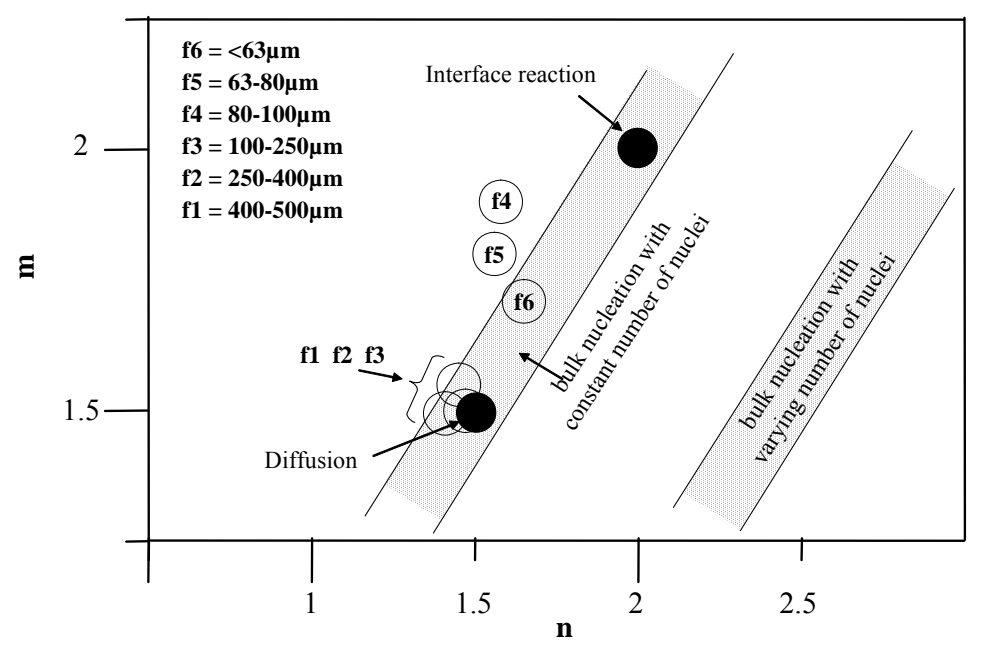

Figure 11. Plot of $\mathrm{n}$ and $\mathrm{m}$ parameters for $\mathrm{fl}-\mathrm{f6}$ fractions comparing to different crystallization mechanisms according to Matusita et al. [34].

\section{Conclusions}

The effect of particle size on crystallization kinetics and growth mechanism of an ironrich glass produced by melting a waste coming from nickel hydrometallurgical production have been investigate by DTA method on a glass prepared by mixing $30 \%$ waste, $60 \%$ glass cullet and $10 \%$ dolomite. From the experimental results the following conclusions can be drawn:

- The temperature of the maximum of the exothermic peak shifts to higher temperatures as the particle size decrease from 500 to $<63 \mu \mathrm{m}$.

- The average activation energy, E, of pyroxene phase devitrification for the different particle size fractions is in the $349-423 \mathrm{~kJ} \mathrm{~mol}^{-1}$ interval. The arrangement of $\mathrm{E}$ with particle size indicates that crystallization in the glass occurs by different mechanisms depending on the glass particle size, being $100 \mu \mathrm{m}$ the critical particle size.

- The values of the calculated growth morphology parameters, $\mathrm{n}$ and $\mathrm{m}$, indicate that bulk nucleation from a constant number of nuclei is the dominant mechanism for pyroxene crystallization.

- Glass fractions with particle size $>100 \mu \mathrm{m}$ show values of $\mathrm{n}$ and $\mathrm{m}$ parameters close to 1.5 , indicating a three-dimensional growth of crystals with polyhedron-like morphology.

- Glass fractions with particle size $<100 \mu \mathrm{m}$ show values of $\mathrm{n}$ and $\mathrm{m}$ parameters shifted to 2 , indicating an interface reaction mechanism with two-dimensional growth of crystals with plates-like morphology.

- The values of the frequency factor, $k_{o}$, are in the $3.72 \times 10^{15}-1.40 \times 10^{19} \mathrm{~s}^{-1}$ range and show a strong change around the critical particle size. 


\section{Acknowledgement}

This investigation has been carried out in the frame of a co-operation project between the Spanish Council for Scientific Research (CSIC) and the Slovak Academy of Sciences (SAS).

\section{References}

1. G. PARTRIDGE, Glass Technol. 35 (1994) 116-127.

2. G. PARTRIDGE, Glass Technol. 35 (1994) 171-182.

3. P. F. JAMES, J. Non-Cryst. Solids, 181 (1995) 1-15.

4. W. PANNHORST, J. Non-Cryst. Solids, 219 (1997) 198-204.

5. W. HÖLAND and G. BEALL, in "Glass-ceramic technology" (The American Ceramic Society, Ohio, 2002).

6. W. BOCOLA and A. DONATO A, Energia Nucleare 19 (1972) 6, p. 390.

7. A. DONATO and W. BOCOLA, Energia Nucleare 19 (1972) 7, p. 459.

8. M. HIDALGO and J.MA. RINCÓN, Bol. Soc. Esp. Ceram. Vidr. 26 (1987) 227234.

9. I. W. DONALD, B. L. METCALFE and R. N. J. TAYLOR, J. Mater. Sci. 32 (1997) 5851-5887.

10. P. HRMA, J. V. CRUM, D. J. BATES, P. R. BREDT, L. R. GREENWOOD and H. D. SMITH, J. Nucl. Mater. 345 (2005) 1, 19-30.

11. P. HRMA, J. V. CRUM, P. R. BREDT, L. R. GREENWOOD, B. W. AREY and H. D. SMITH HD, J. Nucl. Mater. 345 (2005) 1, 31-40.

12. C. P. KAUSHIK, R. K. MISHRA, P. SENGUPTA, A. KUMAR, D. DAS, G. B. KALE and K. RAJ, J. Nucl. Mater. 358 (2006) 2-3, 129-138.

13. R. D. RAWLINGS, P. WU and A. R. BOCCACCINI, J. Mater. Sci. 41 (2006) 3, 733-761.

14. M. ROMERO and J.MA. RINCÓN, J. Am. Ceram. Soc. 82 (1999) 1313-1317.

15. A. KARAMANOV, G. TAGLIERI and M. PELINO, J. Am. Ceram. Soc. 82 (1999) 3012-3016.

16. A. KARAMANOV, P. PISCIELlA and M. PELINO, J. Eur. Ceram. Soc. 20 (2000) 2233-2237.

17. P. KAVOURAS, T. A. LOANNIDIS, T. KEHAGIAS, I. TSILIKA, K. CHRISSAFIS, S. KOKKOU, A. ZOUBOULIS and T. KARAKOSTAS, J. Eur. Ceram. Soc. 27 (2007) 5, 2317-2323.

18. P. KAVOURAS, T. KEHAGIAS, I. TSILIKA, G. KAIMAKAMIS, K. CHRISSAFIS, S. KOKKOU, D. PAPADOPOULOS and T. KARAKOSTAS, J. Hazard. Mater. 139 (2007) 3, 424-429.

19. M. PELINO, A. KARAMANOV, P. PISCIELLA, S. CRISUCCI and D. ZONETTI, Waste Manage. 22 (2002) 8, 945-949.

20. A. KARAMANOV, M. ALOISI and M. PELINO, J. Hazard. Mater. 140 (2007) 12, 333-339.

21. A.A. FRANCIS, R.D. RAWLINGS, R. SWEENEY and A.R. BOCCACCINI, J. Non-Cryst. Solids 333 (2004) 187-193.

22. S. SURINACH, M. D. BARO, M. T. CLAVAGUERA and N. CLAVAGUERA, J. Non-Cryst. Solids 58 (1983) 209-217. 
23. R. A. LIGERO, J. VAZQUES, M. CASAS-RUIZ and R. A. JIMÉNEZ-GARAY, J. Mater. Sci. 26 (1991) 211-215.

24. A. L. CAMPOS, N. T. SIlVA, F. C. L. MELO, M. A. S. OLIVEIRA and G. P. THIM, J. Non-Cryst. Solids 304 (2002) 9-24.

25. P. WEI and L. RONGTI, Mat. Sci. Eng. A 271 (1999) 298-305.

26. M. ROMERO, J. MARTÍN-MÁRQUEZ and J.MA. RINCÓN, J. Eur. Ceram. Soc. 26 (2006) 1647-1652.

27. K. MATUSITA, S. SAKKA and Y. MATSUI, J. Mater. Sci. 10 (1975) 961-966.

28. K. MATUSITA and S. SAKKA, Phys. Chem. Glasses 20 (1979) 81-84.

29. K. MATUSITA and S. SAKKA, J. Non-Cryst. Solids 38-39 (1980) 741-746.

30. W. A. DEER, R. A. HOWIE and J. ZUSSMAN, in "The Rock-Forming Minerals" (Pearson Education Limited, Essex, 1992) p. 170.

31. M. ROMERO and J.MA. RINCON, J. Eur. Ceram. Soc. 18 (1998) 153-160.

32. A. KARAMANOV and M. PELINO, J. Non-Cryst. Solids 281 (2001) 139-151.

33. J. MA. RINCÓN, Polym. Plast. Technol. Eng., 31 (1992) 309-357.

34. K. MATUSITA, K. MIURA and T. KOMATSU, Thermochim. Acta 88 (1985) 283-288. 